\title{
What if? An Experiment to Include a Religious Narrative in the Approach of the European Court of Human Rights
}

\author{
Anicée Van Engeland \\ Senior lecturer, Centre for International Security and Resilience, \\ Cranfield University
}

\begin{abstract}
According to some interpretations of Islam supported by gender activists, the veil can be perceived as a passport that enables women to participate in public affairs. This argument has been overlooked by the courts, including the European Court of Human Rights. The latter has adopted a discourse that considers the veil to be a threat to public order and gender equality, and more recently, an obstacle to social cohesion. By doing so, the Court has excluded veiled European Muslim women from the public sphere. The Court has justified curbing freedom of religion by granting states a wide margin of appreciation on the basis of the concept of "living together." I argue that the Court needs to take the "passport veil" into account to be consistent with its argument on living together. A shift of approach and discourse would constitute a new way of understanding integration through the veil.
\end{abstract}

\section{Keywords}

European Court of Human Rights - Islam - veil - social cohesion

\section{Introduction}

Recent cases have shown that veiled Muslim women face challenges in the European public sphere. ${ }^{1}$ In the name of social cohesion, or of "living together,"

1 See, e.g., Cass., Soc., 19 Mars 2013, Mme Fatima X..., épouse Y... c/ L'Association Baby Loup, No 11-28.845; the S.A.S. v. France 43835/11 ECHR (o1 July 2014); the decision of the Spanish

(C) KONINKLIJKE BRILL NV, LEIDEN, 2019 | DOI 10.1163/22124810-00702004 
le vivre ensemble, as referred to by French and Belgian authorities, they are encouraged to integrate into society. The relevant domestic and European case law, however, has indicated that women wearing a full or partial veil (all categories and types included, from the chale to the burqa) have limited women's access to education and work. ${ }^{2}$ Muslim women are consequently caught between two prohibitions: one dictated by expectations and demands stemming from their beliefs or their community, the other dictated by courts, such as the European Court of Human Rights (ECtHR), and by domestic law. ${ }^{3}$ Women are told both to veil and not to veil, and their access to the public sphere is monitored, if not restricted. As a result, it seems that European Muslim women who wear the veil are expected to choose between their beliefs and integration. They are torn between "overlapping systems of identification." ${ }^{4}$ This is not a new phenomenon, and it was already denounced in the context of colonialism by those like Fannon in his mask analogy. ${ }^{5}$ The novelty resides in the attempt to resolve this tension by encouraging courts to consider alternative readings of the veil. The aim of this article is to encourage legal professionals to embrace a scenario in which the veil is understood as contributing to women's empowerment rather than as a threat to equality or national security. The article relies on Muslim feminists' writings that provide interpretations seeking to reconcile faith with gender equality. The veil then becomes a passport (I call it a "passport veil"), enabling women to cross the border between the private and the public spheres, the religious and the secular spheres, all along respecting their own values. Such an interpretation could make it possible for courts to view the phenomenon of the veil differently. ${ }^{6}$

This article forms the basis for an experimental testing of the attitude of a secular court toward the religious narrative of the veil as a tool of women's

Supreme Court overturning a city ban on face-covering veils in municipal buildings (Asociación Watani para la Libertad y la Justicia v. Lleida, Tribunal Supremo, Sala de lo Contencioso-Administrativo, Sección: Séptima, o6 Febrero 2013, Recurso casacion Numero: 4118/2011); and $B$ and $M$ v. Secretary of State for the Home Department [2013] EWHC 2281 (Admin).

2 See ECtHR decisions: Karaduman v. Turkey, App. No. 16278/90, 74 Eur. Comm'n H.R. Dec \& Rep 93 (1993); Dahlab v. Switzerland, $42393 / 98$ [2001] Eur Ct H R 449 (15 February 2001); Şahin v. Turkey, 44774/98 [2004] Eur Ct H R 299 (29 June 2004).

3 For example, the French law criminalizing the wearing of face veils: LOI $\mathrm{n}^{\circ} 2010-1192 \mathrm{du} 11$ October 2010 interdisant la dissimulation du visage dans l'espace public.

4 Ayelet Shachar, "Privatizing Diversity: A Cautionary Tale from Religious Arbitration in Family Law", 9(2) Theor Inq Law (2008), 573 .

5 Frantz Fanon, Black Skin, White Mask (1952).

6 Will Kymlicka and Raphael Cohen-Almagor, "Democracy and Multiculturalism”, in R. CohenAlmagor (ed.), Challenges to Democracy: Essays in Honour and Memory of Isaiah Berlin (2000). 
empowerment. To frame this scenario, I need to set aside set aside existing interpretations of Article 9 of the European Convention on Human Rights (ECHR) by the ECtHR, which has prevented accommodating the veil. I suggest changing the way we perceive religion, and move toward accommodation, seeking to understand how religion can play a positive role when interpreting the Convention. ${ }^{7}$ This experiment represents an opportunity to promote cultural diversity in the judicial narrative. ${ }^{8}$ The ECtHR, for example, in Chapman v. the United Kingdom, ${ }^{9}$ has referred to the concept of cultural diversity. The article seeks to put into action the judges' words in the Chapman case, where they considered the protection of the lifestyle and identity of minorities as "a cultural diversity of value to the whole community."10 I therefore challenge existing limitations when adjudicating minorities' issues in courts by asking "what if?:" What if the ECtHR were to consider an internal religious narrative such as the one promoted by Islamic feminists? What benefits could be reaped from listening to other ideas and perspectives on the veil? I believe that secular judges, guided by experts, can understand Muslim women's pleas and practice multiculturalism while engaging with interculturalism in courts and their judgments. Some British courts have considered such narratives, as demonstrated by the decision in 2017 that led a judge to severely limit visitation rights of a transgender woman on the grounds that it would cause harm to children belonging to a Jewish ultra-Orthodox community. ${ }^{11}$ My argument is to be understood as a contribution to multiculturalism, looking at a judicial effort to protect veiled European Muslim women, and to interculturalism, considering the role of the judiciary in supporting the circulation of other views and the evolution of culture through law. Both multiculturalism and interculturalism can be achieved by taking into account internal religious perspectives that are called to play a role in a secular environment.

The ECtHR constitutes an excellent forum for this experiment. The aim is not to establish the ECtHR as the authoritative body when it comes to deciding on Muslim issues, nor to institute a neo-imperialist approach that could lead to European judges deciding what Islam is. The ECtHR is intended to protect human rights, operating in a secular environment while deciding, among others,

\footnotetext{
7 George Letsas, “Accommodating What Needn't Be Special”, 10(2) L. \& Eth. H.R. (2016), 319.

8 See the 2001 Unesco Universal Declaration on Cultural Diversity: http://portal.unesco .org/en/ev.php-URL_ID=13179\&URL_DO=DO_TOPIC\&URL_SECTION=201.html

9 Chapman v. the United Kingdom, 27238/95 [2001] Eur Ct H R 43 (30 January 2001).

$10 \quad$ Ibid., $§ 93$.

11 J.B. and The Children (Ultra-Orthodox Judaism: Transgender) [2017] EWFC 4, 30 January 2017 .
} 
on religious issues. It finds itself in a unique position, having to examine subjective considerations with regard to religion, culture, and traditions, while upholding the democratic and human rights values enshrined in the ECHR. The Court has reviewed such cases applying tests like the margin of appreciation. It is therefore in a position to hear the internal religious perspective of European Muslim women while protecting European values, practicing multiculturalism and interculturalism on the basis of a cross-cultural dialogue.

This experiment calls for a reappraisal of the stories of Senay Karaduman, Lucia Dahlab, and Leyla Şahin (to name a few), each of whom sought to graduate, work, or receive an education, but was denied the opportunity by the ECtHR. Most Muslim women living in Europe seek to be empowered and want to contribute to society. One of their strategies is to redefine their identities that have become plural: they need to accommodate Islam with the values of the country they live in, working at two levels. ${ }^{12}$ I suggest that the judges should have considered alternative religious narratives, while honouring the principles laid out in the Convention. My argument in this experiment is that law-making could rely on contextualized gender views. ${ }^{13}$ Having established that Islamic feminism and the passport veil could provide a culturally or religiously sensitive solution to the integration of Muslim women, I argue that the ECtHR should be encouraged to look at gender and Islam from an inclusive perspective, concentrating on contextualized needs, which in turn can lead to a consideration of Islamic feminism.

\section{Gender Jihad: Addressing Muslim Women's Rights}

To sustain the argument that an internal religious perspective should be considered by a secular court, it is necessary to understand this religious narrative's role vis-à-vis some European Muslim women, with reference to empowerment. This part also outlines the strategy of the passport veil, a term I propose to use.

\subsection{Islamic Feminism and the Passport Veil}

Islamic feminism exists throughout the Muslim world, and its supporters have achieved some important breakthroughs. They use Muslim legal techniques to examine sources of law from a gender-oriented perspective, then reinterpret

12 Amber E. Kinser, "Negotiating Spaces for/through Third-Wave Feminism", 16(3) NWSA Journal (2004), 124.

13 Hillary Charlesworth and Chirstine Chinkin, The Boundaries of International Law: a Feminist Analysis (2000), 62. 
the tradition in light of gender equality. The benefit of referring to Islamic texts is that it enables women to seek equality and empowerment within the Islamic framework, remaining faithful to their religious beliefs and identity while looking for what they believe is duly theirs in Islam. As summarized by Wadud, Islamic feminisms (there are different approaches to feminism in Islam), are gender policies that encourages women's active participation in the tradition, so that their needs, realities, and experiences can be reflected in their interpretations; it is about how we live vs. how we are supposed to live. ${ }^{14}$ Islamic feminism provides a context for the passport veil: the narrative advanced by these gender activists is grounded in the reality of many Muslim women, reflecting their needs or expectations. This is why the ECtHR should look into Islamic feminism when appraising the veil: it would help explain how some European Muslim women approach their own religion and understand their contribution as citizens. Understanding the passport veil helps contextualise certain claims made by some of the veiled women seeking adjudication of their claim that the veil is a liberating tool.

Part of the argument on the passport veil as a liberating tool is the use of the veil to cross borders, or walk along the boundary that separates the private sphere from the public sphere. Here, the private sphere is defined as the family, friends and community. In the private space, one can contribute to the "production and performance of cultural identities."15 The public space includes streets, shops, as well as areas that are vetted by the community, such as mosques. Yet this distinction is somewhat unhelpful when it comes to Islam as what happens in a public space such as a mosque can influence the behavior of a woman at home. The public/private narrative is therefore multidimensional and I have adapted it to this article so that the public sphere remains the space where veiled Muslim women interact with the state. ${ }^{16}$ When using the passport to cross the border between the private and the public, women introduce a new narrative into the environment of the state as they seek to

14 Amina Wadud, "Islamic Feminism". Paper presented at Cornell College. 22 April 2010. Retrieved 15 February 2017, http://news.cornellcollege.edu/2010/04/amina-wadud-talks -about-islamic-feminism/.

15 Ayona Datta, "Making Space for Muslims: housing Bangladeshi families in East London", in R. Phililips (ed.), Muslim Spaces of Hope: Geographies of possibilities in Britain and the West (2009).

16 Shachar noted that the threshold for crossing from the private to the public is far from clear, and cited the work of Frances E. Olsen, "The Family and the Market: A Study of Ideology and Legal Reform", 96 Harv L Rev (1983), 1497, in Ayelet Shachar, "On Citizenship and Multicultural Vulnerability", 28:1 Pol Theory (2000), 64-89. 
construct their own identity in the public space. ${ }^{17}$ Against this backdrop, the public space becomes a location where the state is deployed and where the majority rules, as clearly stated by the Court when using the "living together" yardstick in the case law analyzed below. Negotiating the passage from the private sphere, where the family and the community are often omnipresent, to the public space, which is often somewhat secular, presents different challenges for men and women. Crossing the borders can prove awkward for both if external signs of belonging are present in the form of a veil or some other pieces of clothing.

Besides reading the intentions of the Prophet and looking into the philosophy of Islam with regard to gender equality, Islamic feminists insist on taking into account the context in which women live. Wadud suggested that the veil is to be understood within the culture and the context; ${ }^{18}$ she analyzed the meaning of the veil in each context and went through the phases of veiling and unveiling that an individual experiences. This demonstrates the diversity of the motivations for wearing the veil. ${ }^{19}$ These motivations were exposed in the $S A S$ and the Belcacemi and Oussar cases. ${ }^{20}$ Fakhro suggested using Sharur's theory of the maximum and the minimum of tolerable limits of acceptability, to check whether the veil is to be worn in a certain context: a naked woman and an entirely covered woman are outside the spectrum of respectability, and a woman must adapt her veiling to the context in which she lives. ${ }^{21}$ This approach demonstrates the array of possibilities when it comes to accommodating the veil.

Can this form of empowerment provided by Islamic feminisms serve some European Muslim women, especially before the courts? Or is this struggle for gender equality too specific to Islam, and incompatible with the mission and purpose of the ECtHR?

\subsection{Emancipation and the Veil}

Part of the perception of the veil as an instrument for emancipation is a reaction to recent history, when the veil was either perceived as an instrument of

17 Caroline Nagel and Lynn Staeheli, "British Arab Perspectives on religion, politics and the 'public', in P. Hopkins and R. Gale (eds.), Muslims in Britain: Race, Place and Identities: Race, Place and Identities (2013), 96.

18 Amina Wadud, Qur'an and Woman: Rereading the Sacred Text from a Woman's Perspective (New York, 1999).

19 Wadud, supra note 35.

20 Belcacemi and Oussar v. Belgium, 37798/13 [2017] Eur Ct H R (11 July 2017); Dakir v. Belgium 4619/12 [2017] Eur Ct H R (11 July 2017).

21 Munira Fakhro, "Gulf Women and Islamic Law", in M .Yamani (ed.), Feminism and Islam: Legal and Literary Perspectives (1996), 253-254. 
resistance or as a means of preventing empowerment, as illustrated by the 2010 French law. The veil as a passport is a radically different approach: it describes the veil as being owned by women. Rather than being part of a nationalistic discourse in a (post-) colonial environment, Muslim women have given a new meaning to being veiled, considering it as the opportunity to cross borders, and thus becoming autonomous individuals and citizens. This perception builds on the idea that the veil “form(s) part of Muslim women's character, behaviour and identity." ${ }^{22}$ In this regard, the passport veil empowers us to think of veiled European Muslim women as individuals, rather than analyzing them from a collective or Euro-centric perspective. Therefore, women should not be considered objects on which we project our theories about emancipation or resistance, which is why it is important to consider alternative theories such as the one of the passport veil.

This is the context in which some Islamic feminists think about the veil as an empowering instrument: the veil should be interpreted first as a choice, then as a way of gaining societal mobility. As submitted by sAs in her case at the ECtHR, the idea that a woman covering her face is "incompatible with the principle of gender equality [...] is simplistic. She added that the wearing the veil could denote emancipation, self-assertion and participation in society; far from wearing the veil to reinforce patriarchy, sAs believes she did it because of her own faith and stated that she was being "denied the right to exist as individuals in public, when in the majority of cases it was worn voluntarily and without any proselytising motive." ${ }^{23}$ In Belcacemi and Oussar v. Belgium, both women explained that they wore the full veil by choice. ${ }^{24}$ Ms. Dakir expressed the same motivation and choice ${ }^{25}$ Both appellants also explained the effect that the Belgian law had on their lives, effectively depriving them of the passport that would enable them to cross borders. ${ }^{26}$ By adopting this strategy of wearing the veil, Islamic feminists and gender activists challenge the conservative agenda through the reappropriation of "the veil as a means to facilitate social presence rather than seclusion." ${ }^{27}$ Such stances illustrate Shachar's argument that there is room for enhancing minorities' autonomies through the

\footnotetext{
22 Rajnara Akhtar, "Islam and the Veil: Theoretical and Regional Contexts", in T. Gabrial and R. Hannan (eds.), Islam and the Veil: Theoretical and Regional Contexts (2011), 149. 
courts. $^{28}$ It is to be noted that in SAS v France, the Court heard this argument and rejected the notion that the veil contradicts gender equality, stating that "a State Party cannot invoke gender equality in order to ban a practice that is defended by women - such as the applicant - in the context of the exercise of the rights enshrined in those provisions, unless it were to be understood that individuals could be protected on that basis from the exercise of their own fundamental rights and freedoms." ${ }^{29}$ The veil is consequently, in many ways, a symbol of Islamic feminisms, as demonstrated on social media and various blog entries and articles. ${ }^{30}$ This is why Ahmed spoke of the Islamic dress as a sign of "educational and professional upward mobility" and a "practical coping strategy, enabling women to negotiate in the new world while affirming the traditional values of their upbringings." ${ }^{31}$ She called this empowerment a "quiet revolution."32 Indeed, it is when women "reclaim their own cultures, interpreting texts and traditions in self-empowering ways... [that] women may truly claim their rights." ${ }^{33}$ Silvestri notes that while Muslim women battled against the veil as an imposition, others considered it as "a path to emancipation, whereby Muslim women assert their right to free choice and stand up for and articulate their own human rights within a secular context." ${ }^{34}$ Kapur has also said "the veil has also been a very empowering symbol for Muslim women in some countries... Amongst immigrant communities in the West, it is the symbol of an exclusive cultural space and a rejection of assimilation." 35 Odeh concluded that "unless I engaged in intellectual elitism and accused

28 Aylet Shachar, Multicultural Jurisdictions: Cultural Differences And Women's Rights (2001), 3 .

$29 S A S$ v. France, $§ 119$.

3o Nadiya Takolia, "The hijab has liberated me from society's expectations of women", The Guardian. 28 May 2012. Retrieved ${ }_{15}$ February 2017, http://www.theguardian.com/commentisfree/2012/may/28/hijab-society-women-religious-political; Pina Sadar, "Muslim Feminists reclaim the hijab in fight against patriarchy", The Conversation. 26 September 2014. Retrieved 15 February 2017, http://theconversation.com/muslim-feminists-reclaim-the -hijab-to-fight-the-patriarchy-31126

$31 \quad$ Ibid.

32 Leila Ahmed, A Quiet Revolution: The Veil's Resurgence, from the Middle East to America (2011).

33 Mahnaz Afkhami and Haleh Vaziri, Victories Over Violence: Ensuring Safety for Women and Girls A Practitioner's Manual (1998), 9.

34 Sara Silvestri, "Unveiled Issues: Reflections From A Comparative Pilot Study On Europe's Muslim Women", City University London Working Papers on Transnational Politics. April 2009. Retrieved 15 February 2017, https://www.city.ac.uk/_data/assets/pdf_file/oo16/ 84040/CUWPTPoo5A.pdf.

Ratna Kapur, Erotic Justice: Law and the New Politics of Colonialism (2005), 107. 
those women of false consciousness and of not knowing their own good, there was no way I could point to instances of the disempowerment of the veil." ${ }^{36}$ And El Guindi concluded that the veil "is feminist because it seeks to liberate womanhood."37

\subsection{Of the use of the Passport Veil}

To fully understand the challenge the ECtHR faces when ruling in cases involving the veil, and to comprehend the scope and stakes of my experiment, it is useful to understand how the passport veil functions. I suggest that a secular court consider an internal religious perspective in the name of multiculturalism. It is therefore necessary to analyze in depth how a product of that internal religious narrative works, and to see whether it could be considered by the courts.

The veil is a complex, subtle, and flexible instrument for negotiating spaces, borders, and plural identities, and it can empower women in a trade-off, or a strategic choice as explained by Aksoy and Gambetta. ${ }^{38}$ The idea of a trade-off emerges from the work of Abu Odeh, who suggested that veiling was used as a way for women to prevent sexual harassment in public. ${ }^{39}$ In such instances, women use the veil for a given purpose and with the view of gaining a certain outcome. ${ }^{40}$ Therefore, rather than limiting myself to the veil as a metaphor for Muslim women, ${ }^{41}$ I use it as a tool for negotiating freedom, which why I speak of crossing borders. To contextualize this trade-off is to argue that European Muslim women wear the veil, and in return expected the opportunity to play a social role in a secular sphere while upholding their religious beliefs. This is well expressed by the Belgian women who lodged an application with the ECtHR against the 2011 law that banned veiling: one of them had chosen to remove her veil during the proceedings to be able to keep entering the public space. Her rational was that she had family responsibilities that meant she had to be visible in the public space and it has seemed to her best to remove her veil

36 Lama Abu Odeh, "Post-Colonial Feminism and the Veil: Considering the Differences", 26 New Eng. L. Rev. (1991-92), 1527, 1532.

37 Fadwa El Guindi, Veil: Modesty, Privacy and Resistance (1999), 184.

38 Ozan Aksoy and Diego Gambetta, "Behind the Veil: The Startegic Use of Religious Garb", 6:1 Eur Sociol Rev (2016), 792.

39 Abu Odeh supra note 80, 1530-1531.

40 Lila Abu-Lughod, Remaking Women: Feminism and Modernity in the Middle East (1998), 252.

41 Susie Hawkins, "The Essence of the Veil: The Veil as a Metaphor for Islamic Women in Voices", in E. M. Caner (ed.) Behind the Veil: The World of Islam Through the Eyes of Women (2003), 93-106. 
in the meantime to avoid being arrested or being stigmatised. The other lady has chosen to keep the veil and realise that she couldn't leave her home as her passport veil had been removed from her. ${ }^{42}$

The circumstances of the trade-off must be understood so that empowerment can logically follow from them: for women for whom the veil is compulsory, this trade-off means access to public space. ${ }^{43}$ The veil gives them a degree of autonomy through the protection it grants, without fear of community or family sanctions. ${ }^{44}$ This autonomy creates room for empowerment, providing women access to employment and education. ${ }^{45}$ The trade-off empowers women further when they cross the border back from the public to the private space. Duval described an increase in mobility: ${ }^{46}$ having been exposed to the "other" in European secular spheres, Muslim women are empowered to negotiate at home, and even defy authority. ${ }^{47}$ These women indicate that wearing the veil is a way of complying with family or community expectations, expecting in return some recognition in the private sphere. ${ }^{48}$ This could lead to a renegotiation of gender relationships. ${ }^{49}$ This trade-off is illustrated by veiled young women attending universities in exchange for postponing marriage. For women who have willingly embraced the veil, veiling becomes a way of asserting their cultural or religious identity while integrating ${ }^{50}$ in Western society and taking control of their private and public lives. ${ }^{51}$ With access to the social sphere, the trade-off could play a constructive role in building integration and citizenship: the veil helps create a negotiated identity. ${ }^{52}$ This is why veiling is

\footnotetext{
42 [full reference] Belcacemi and Oussar v. Belgium, § 9-10.

43 Fadwa El Guindi, "Veiling infitah with Muslim ethic: Egypt's contemporary Islamic movement", 28(4) Social Problems (1980), 465-485, 482

44 Katherine Bullock, Rethinking Muslim Women and the Veil: Challenging Historical \& Modern Stereotypes (2002), 185; Carrie Rosefsky Wickam, Mobilizing Islam: Religion, Activism, and Political Change in Egypt (2002), 133.

Asma Afsaruddin, Hermeneutics and Honor: negotiating female "public" space in Islamic/ ate societies (1999), 19; Soroya Duval, "New veils and new voices: Islamist women's groups in Egypt", in K. Ask and M. Tjomsland (eds.), Women and Islamization: Contemporary Dimensions of Discourses on Gender Relations (1998), 45-72, 63.

46 Duval, ibid., 63.

47 Afsaruddin supra note 93, 16.

48 El Guindi supra note 91, 79; Afsaruddin, supra note 93, 7.

49 Duval, supra note 93,63 .

$50 \quad$ Ibid., 61.

$51 \quad$ Afsaruddin, supra note 93, 16.

52 Valorie K. Vojdik, "Politics of the Headscarf in Turkey: Masculinities, Feminism and the Construction of Collective Identities", 33 Harv J L \& Gender (2010), 661-685, 664.
} 
generally discussed by Muslim feminist scholars in relation to the woman as a subject, in addition to a discussion with respect to the social fabric.

Crossing borders with the aid of the veil means transcending the privatepublic divide. Admittedly, it has at times been associated with other dichotomies such as "us/them" or "Muslim/European values." A source of these dichotomies is to be found in yet another dichotomy, that of "honour/shame," which provides guidelines about how a woman should behave. ${ }^{53}$ Women are expected to behave in a way that upholds their honour as well as that of the family and the community. Crawley summed it up by stating that "dress is the most distinctive expression in a material form of the various grades of social life. The biological period thus becomes a social period of existence and the individual is merged in a functional section of the community" 54 As a result, the veil has been used to control women's bodies, ${ }^{55}$ to separate them from the rest of the society. ${ }^{56}$ This control, which could arguably amount to oppression, has been emphasized in conservative interpretations of Islamic scriptures pertaining to the veil. This means that the ECtHR is correct when it denounces the veil as a tool of oppression (as explained below); yet, when the court does so, it considers only some of the interpretations provided by some Muslim Conservative clerics. It examines only conservative readings of Islam, and ignores Muslim feminist readings. If the judges were to listen to women's narratives on empowerment, they would become aware of the fact that by using the veil as a means to achieving emancipation, women negotiate the framework of shame and honour. This manipulation of the private/public divide and of other divides is central to feminist resistance ${ }^{57}$ and crucial to understanding the stakes in the case of some Muslim women's path to empowerment. With the passport veil, Muslim women turn the argument of the veil as an instrument of protection from the male gaze on its head: they accept wearing it to be protected in public, and in exchange expect to fully contribute to social activities. The veil becomes more than a passport to cross the divide; it also becomes a way of controlling one's destiny through appropriation of the public space. ${ }^{58}$ Considering the passport veil enables us to understand why some women decide to

\footnotetext{
53 El Guindi, supra note 91, 79.

54 Alfred Ernest Crawley, Dress, drinks and drums (1931), 117.

55 Fatima Mernissi, L'amour dans les pays musulmans (2009), 74.

56 Fatima Mernissi, Women and Islam: A historical and theological enquiry (1991), 178-9.

57 Shirley Ardener, Women and space: Ground rules and social maps (1981), 3; Afsaruddin, supra note 93, Introduction.

58 Duval, supra note 93, 63 .
} 
appeal to the courts to protect their right to wear a veil: they seek validation from the state apparatus of their internal narrative.

Although the argument of the passport veil has been presented by applicants to the ECtHR, the Court did not approach the veil as an instrument of empowerment, but rather as a form of oppression that has a negative effect on gender equality. By doing so, the Court denied veiled women the opportunity to pursue personal autonomy through alternative means. The $S A S$ v. France case raised hope for a change, as the Court did not discard the argument of empowerment, but decided that "living together" superseded it. In subsequent case law concerning Belgium, in 2017, however, the judges did not elaborate on the choice made by women, and chose instead to develop the "living together" concept. Exclusion

The early case law of the Court demonstrates a stereotyped understanding of Islam and the veil. It used well-established yardsticks to justify its balanced approach, finding equilibrium between freedom of religion and state interests, as the two 2017 cases concerning Belgium demonstrated. In the cases from 2017, the ECtHR missed an opportunity to develop its view on women's empowerment, choosing instead to develop the concept of living together. This is why I frame my work as an experiment: I seek to demonstrate what would happen if the ECtHR were to accommodate a certain religious approach in an intercultural spirit (knowing that others may raise the issue of selecting which intercultural narrative we should listen to), being aware of the subjectivity of the concept of the passport veil, given that not all Muslims adhere to it.

\subsection{Stereotyping the Veil: Overview of ECtHR Case Law}

The ECtHR has had to decide on cases involving the veil. It has often done so by portraying the veil and Islam negatively, as for example in Karaduman v. Turkey, where the Commission stated that "where secular universities have laid down dress regulations for students, they may ensure that certain fundamentalist religious movements do not disturb public order in higher education or impinge on the beliefs of others." 59 This balance, however, has been reached on weak grounds because the Court opted for a conservative portrayal of Islam, ignoring the positive and reformist Muslim elements, such as Islamic feminism.

59 Karaduman v. Turkey, pp. 107-108. 
The Court did not take into consideration the fact that there is a liberal form of Islam, which could be in agreement with the democratic and human rights purposes of the ECHR.

ECtHR jurisprudence also reveals a stereotypical view of the veil. For example, it depicts it as "powerful external symbol." ${ }^{60}$ Measuring the effect of the veil on young children when worn by a teacher, the Court stated that:

[I]t cannot be denied outright that the wearing of a headscarf might have some kind of proselytising effect, seeing that it appears to be imposed on women by a precept which is laid down in the Koran and which... is hard to square with the principle of gender equality. It therefore appears difficult to reconcile the wearing of an Islamic headscarf with the message of tolerance, respect for others and, above all, equality and nondiscrimination that all teachers in a democratic society must convey to their pupils. ${ }^{61}$

The ECtHR viewed the headscarf as the symbol of a religion, which is only one interpretation of veiling, but which also happens to be the understanding proffered by many conservative Muslim interpreters. ${ }^{62}$ With such statements, the Court merely confirms traditional and patriarchal Muslim readings, and can conclude only that the veil is contrary to gender equality and empowerment. The Court therefore silenced the women, denying them the possibility to be autonomous bodies, because they are perceived as being subjected to an external compelling force. The veil is also perceived as a threat to public order. In Karaduman, the veil was described as an aggressive symbol, capable of creating social conflict, and wearing the veil could challenge those who do not wear one. ${ }^{63}$ In Şahin, it was described as threatening democratic values:

The Court also notes that in the decisions in Karaduman and Dahlab, the Convention institutions found that in a democratic society the State was entitled to place restrictions on the wearing of the Islamic headscarf

\footnotetext{
6 Dahlab v. Switzerland.

61 [full citation] Dahlab v. Switzerland.

62 For an in-depth analysis of the new hermeneutics on the veil, see the work by the Lebanese scholar, Zin al-Din, who found 10 different interpretations of the verses of the Quran in relation to veiling, as cited in Shabaan (Bouthaina Shabaan, "The Muted Voices of Women Interpreters", in Mahnaz Afkhami (ed.), Faith and Freedom: Women's Human Rights in the Muslim World (1995), 61-77.)

63 Karaduman v. Turkey, 108.
} 
if it was incompatible with the pursued aim of protecting the rights and freedoms of others, public order and public safety. ${ }^{64}$

Another rationale the Court used to justify its approach to the veil was the general context of the rise of Islamism. In Karaduman, a student could not receive her degree because of her photo, in which she appeared veiled. The Commission noted that the university enforced secular rules to ensure harmony among students, during times of rising extremism. ${ }^{65}$ In Leyla Şahin, a university student was not allowed to take her exams because she wished to wear her hijab, in violation of the law. The ban against the hijab relied on the Refah Partisi case, which does not address the veil but Islamism, and was justified by the attempt of the state to curb the influence of extremism. The judges stated in the Refah Partisi that "the Court does not lose sight of the fact that there are extremist political movements in Turkey which seek to impose on society as a whole their religious symbols and conception of a society founded on religious precepts." ${ }^{\prime 6}$ This argument is mentioned also in the $S A S$ case, in relation to the legislative history of the French law of 2010 banning full-face veiling. The Belgian cases brought in 2017 also fall back on the security argument. Thus, the veil has consistently been associated with extremism. In so doing, the Court endorsed a single narrative according to which the veil is a risk to democracy, and never sought to look into the counter-narrative, that the veil can contribute to democracy, indirectly endorsing the philosophy supported by the French and Belgian veil bans that the veil is a threat to the social fabric and to democracy. As summed up by Judge Tulkens, "the headscarf cannot be associated with fundamentalism... Not all women who wear the headscarf are fundamentalists and there is nothing to suggest that the applicant held fundamentalist views." ${ }^{7}$ By side-lining the women who petitioned the ECtHR to adjudicate their claim that wearing the veil is part of their human rights, the Court missed several opportunities to consider the benefits of multiculturalism or with interculturalism by examining a religious perspective. It did conduct religious analysis, however, and sided with conservative views. The question that arises is one of choosing internal narratives: Why did the Court endorse conservative interpretations concerning the veil?

\footnotetext{
64 Şahin v. Turkey, § 111.

65 Karaduman v. Turkey, 108.

66 Refah Partisi and Others v. Turkey 41340/98;41342/98;41343/98 and 41344/98 [2001] ECHR 495 (31 July 2001) § 123 .

67 Şahin v. Turkey, § 10.
} 
In all these cases, the Court used the margin of appreciation as the yardstick to measure the freedom of religion of an individual against the interests of the state. Yet, the balancing exercise between the rights of the individual and state interest did not take into account the cultural and religious beliefs of individuals and the veil as reflecting an identity. The argument put forward by Judge Spano and endorsed by Judge Karakas was that the majority of a society sets the tone, which explains why the court applied the principle at the expense of a minority. ${ }^{68}$ I suggest that the balancing effort of the Court should not rely on a negative depiction of Islam. The social reality of the veil as an instrument, as argued by Islamic feminists, has not been taken into consideration. I believe that Judge Spano's argument about the majority vs. the minority view should be changed: the discussion should not be framed from the perspective of a majority holding democratic values vs. a minority associated with a security threat. Rather, the Court should endeavour to encourage a cross-cultural exchange. The Court should consider social, cultural, and religious beliefs as relevant because its role is to champion the rights of the minority. In present-day Europe, which is de facto multicultural, I believe it is the role of the ECtHR to place religion in context and therefore to look beyond protection alone under Article 9 ECHR, at the risk of becoming the Court of some Europeans as opposed to others. To avoid doing so, the Court must embrace the subjectivity of the appellants; I am not calling for a sacrifice on the part of the collective, of living together, but for a consideration that the subjective experience of European Muslim women has a role to play.

It remains to be seen whether the argument of the veil as an emancipation tool will be considered in future ruling, and whether the Court will elaborate on the "well established feminist position"69 referred to in $S A S$, which reinforces my case for the experiment: What if the ECtHR were to consider this alternative religious narrative according to which the veil could empower some women? And what if the Court were to step away from conservative views on the veil, to look into other readings? The Court certainly did not choose to develop its consideration of subjective views in the Belgian cases in 2017.

\subsection{Consequences of the Rhetoric of the Court: The Exclusion of Women}

The Karaduman, Dahlab, and Şahin cases, among others, dealt with religious paradigms against a secular backdrop and called into question the accommodation of religious and cultural diversity. By opting for a stereotyped reading

\footnotetext{
68 Belcacemi and Oussar v. Belgium, Opinion Concordante Du Juge Spano, à laquelle se rallie la Juge Karakas, $\$ 7$.

$69 \quad$ Ibid., $§ 77$.
} 
of the veil, rather than addressing the issue of religious pluralism in a secular society, the Court effectively excluded veiled Muslim women from the public sphere. Although the $S A S$ v. France case represented a shift in perspective, as it indirectly considered alternative views of the veil, the ECtHR still regarded the veil as an obstacle to socialization and to living together. The outcome of the $S A S$ case was therefore, yet again, exclusion: whereas before women were excluded on the ground of public safety and lack of gender equality, this time they were perceived as either unable to blend into society or as threatening the social fabric. ${ }^{70}$ The veil was seen as an obstacle to social life rather than examined as the opposite, an instrument for socialization. This is the opposite of the passport veil argument.

Yegenoglu characterized the reasoning of the Court as representative of colonial fantasies: the veil is seen as a tool for controlling women's bodies, and women are seen as powerless victims of patriarchy. ${ }^{71}$ It ignores the empowering readings of Islam, offered by Islamic feminists, and does not consider internal religious perspectives that seek equality. Yegenoglu also explained that the cases establish a hierarchy, in which the West stands for gender equality, whereas religion and culture are factors that keep civilization behind. ${ }^{72}$ Mahmood criticised the claim that secularism is by nature emancipatory whereas religion is "totalizing."73 Razack went further, speaking of a policy of expulsion of Muslim women from European public spheres by means of three stereotypical figures: the imperilled Muslim women, the dangerous ones, and the civilized ones. ${ }^{74}$ In the ECtHR cases, the women who sought adjudication were associated with a dangerous category of Muslim women, whose veiling threatens public order or who are associated with the rise of extremism. When women are considered to be victims, the Court associates them with the imperilled women, subjected to Islam and patriarchy, lacking volition This turns women into what Malik called the "other" citizen. ${ }^{75}$ The outcome of the ECtHR case law is the "othering" of veiled Muslim women, which has led to their exclusion from the social sphere.

\footnotetext{
$70 \quad$ Şahin v. Turkey, § 122.

71 Meyda Yegenoglu, Colonial fantasies: Towards a feminist reading of Orientalism (1998), 3-7.

72 Ibid.

73 Saba Mahmood, “Is Critique secular?", 2o(3) Public Culture (2008), 447-452, 449.

74 Sherene Razack, Casting Out: The Eviction of Muslims from Western Law and Politics (2008), 146.

75 Maleiha Malik, “The 'other' citizen: religion in a multicultural Europe”, in Lorenzo Zucca and Camil Ungureanu (eds.), Law, State and Religion in the New Europe: Debates and Dilemmas (2012), 93-114.
} 
This exclusion from European society is the reason why it is urgent to press the Court to think differently and to try the proposed experiment, which could lead them to explore other readings of the role of the veil.

The outcome of the approach followed by the ECtHR is that a stereotyped version of Islam, stemming from a secular institution, replaces a conservative one, originating from the community. Both constitute an attempt to control women's bodies, with the narrative of the Court relying on the argument of emancipation. The outcome is a European paternalism, in addition to Muslim paternalism, as women are told both "veil" and "do not veil." In these circumstances, freedom of choice becomes crucial. It is a real issue for Muslim women to choose whether or not to veil; whether or not to marry; whether or not to work. All the rights established in international and regional documents have no value or function if the beneficiaries of those rights are not empowered to use them. Islamic feminists struggle to empower women to make choices and decide whether or not they want to use women's rights, and within which framework they wish to do it. The ECtHR should strive to protect these women who seek empowerment by considering the arguments put forward regarding the passport veil. It should also encourage alternative views as well as an exchange of views, so that cultures can grow together in the European space. Instead, the Court has created its own narrative, using "gendered and idealized images of women as symbols of group identity."76 It is clear that the purpose of the judges was to empower Muslim women, but the effect, as argued in this paper, is to violate the rights of these women using the very policies aimed at protecting them. ${ }^{77}$ Furthermore, as Radacic stressed, "in dismissing the perspective of a woman in question, the Court pitted the principle of gender equality against the principle of personal autonomy."78 The consequence of putting personal autonomy face-to-face with gender equality is the sacrifice of the empowerment of the individual to society. As stated by Evans:

The women in these cases cease to be individuals with their own personalities, histories and concerns. Instead they become a symbol of the tension between the imagined West (secular, rational, egalitarian, human

76 Ayelet Shachar, "Religion, State, and the Problem of Gender: New Modes of Citizenship and Governance in Diverse Societies", 50 McGill LJ (2005), 50.

77 Shachar, supra note 71 , at 3.

78 Ivana Radacic, "Gender equality jurisprudence of the European Court of Human Rights", 19(4) EJIL (2008), 841-857. 
rights respecting) and imagined Islam (religious fundamentalist, irrational, discriminatory and violative of human rights). ${ }^{79}$

Yet, the message of the Court is clear: the only possibility for empowerment à l'européenne is to shed the veil. This process of exclusion of elements that do not match European values is described by Soirila: veiled Muslim women are treated as a "biopolitical risk" that needs to be "normalized" to "disappear into the mass of the mainstream population, or be excluded from the society." According to Soirila, the ECtHR cannot avoid biopolitical aims, and fulfils them "through discourses that the judges partake of and in cases where the margin of discretion of the Strasbourg judges or the national authorities is increased. ${ }^{80}$ " It seems indeed that some Muslim women have become political pawns in a chess game, and are being compelled to choose between their multiple identities. The division into Muslim women between good ones, who have integrated into society by not wearing a veil, and the dangerous ones, who represent a risk, or the imperilled ones, who are oppressed, should be evaluated against the critical framework suggested by Mahmood, who denounces the idea that there is a conflict between secular necessity and religious threat. ${ }^{81}$ I argue that by considering these women to be a danger to secularism, the ECtHR adopts a laicist understanding of secularism, in which religion becomes the opponent of the state and society. The Court adheres to the dichotomy that one is either against secular values, or in their favor. If "we" do not defend secular values and lifestyles, it is argued, "they," often Islamic extremists, will take over our liberal freedoms and institutions. ${ }^{82}$ Religion in the public sphere becomes a potential danger, and it is necessary to relegate it to the private sphere. As a result, secularism becomes a way of controlling religion, which is obvious when the Court displays fear of indoctrination in Dahlab and in Ciftci. ${ }^{83}$ The attempt to control religion assumed a new form first in the $S A S$ case, and now in the Belcacemi and Oussar and Dakir cases, the threat having evolved from raw Islamic extremism to the subtle undermining of society by veiled women. In such circumstances, the veil cannot be allowed to operate as a passport and can serve only as a religious ID card for living in the private sphere.

\footnotetext{
79 Carolyn Evans, “The 'Islamic Scarf' in the European Court of Human Rights”, 7(1) Melb. J. Int'l L. (2006), 52, 67, 71 .

8o Ukri Soirila, "The European Court of Human Rights, Islam and Foucauldian Biopower", 2 HLR (2011), 365-400, 365 .

81 Mahmood, supra note 124, 449.

82 Ibid.

83 Evrim Ciftçi v. Turkey 59640/oo [2005] ECHR 768 (29 November 2005).
} 
A visa would be granted only if the woman agreed to unveil. This privatization of religion operated by the Court is clearly an issue for veiled Muslim women who use a religious or cultural symbol to leave the private sphere and enter the public sphere. Their passport is not considered valid by the Court. This is why I encourage the Court to experiment by looking into other readings of the veil, including internal narratives, so that the judges can contribute to developing a model of secularism that relies on a Rawlsian overlapping consensus. ${ }^{84}$ In this model of secular state, a veiled woman would be treated equally with all other citizens and would contribute to what she thinks the general good is. The state would adopt a neutral stance toward Muslim women's beliefs, and in return, they would contribute to society by becoming empowered and playing a public role. This framework may entitle veiled Muslim women to move within a rather neutral space in which Islam would play a role. According to advocates of multiculturalism, this would also have a positive effect on cohesion of society. There would be a flow of cultural exchange that would cause society to grow, validating interculturalism as the way forward. This solution can have far-reaching consequences for the way in which secularism is perceived in countries like France, and at the same time point the way to making multiculturalism and interculturalism a reality.

The result of grasping the veil as a political issue rather than perceiving it through the lens of women's stories and subjective views is that the Court approaches veiled Muslim women as objects rather than beings in control of their own lives. The judges' attitude is a negation not only of feminism but also of Islam, an attitude that has been perceived as racist or colonial. ${ }^{85}$ It is clear that the Court is not expected to follow any agenda or engage in judicial activism that would be detrimental to its mission. But considering Islamic feminisms would provide alternative routes to empowerment and gender equality.

SAS v France and Prospects Beyond 2017: Living Together as a New Yardstick

Next, I recommend changing the stance of the Court by pushing my experimentation further, investigating what turn the experiment might take if the ECtHR either adopted a theological approach or focused on personal narratives.

84 Jocelyn Maclure and Charles Taylor, Secularism and Freedom of Conscience (2011), 11-12.

$85 \quad$ Ibid., 67. 


\subsection{The "Living Together" Argument: us vs. Them}

I analyze the ECtHR as a forum for the suggested experiment because it has a framework for thinking about freedom of religion and uses instruments, such as proportionality and the margin of appreciation; it provides a strong basis for the legal reasoning that rejects wearing the veil in a public place. The Court has built an understanding of the role of religion in public life and of the interactions between religious minorities and the state. Yet, this conception is exclusive rather than inclusive, as it grants a wide margin of appreciation to the States when it comes to making decisions about whether or not interference with freedom of religion is needed.

By referring to living together in the $S A S$ case, the Court sidelined religion. The ECtHR respected the approaches to law of nation states. The Court embraced the French and the Belgian "living together" argument to protect the majority of the citizens. The outcome has been dire, leading to the exclusion of the minority. The argument of those who live together according to some values leads to rejecting those who do not, defeating the very purpose of multiculturalism. Therefore, trying to advance an intercultural agenda through the Court seems like endeavour doomed to failure. The outcome of the $S A S$ case needs to be questioned if they do not take into account the views of minorities living within their borders. The argument that only someone who shows her full face ( $S A S$ addressed full-face banning) can be part of the French society, effectively creates an "us vs. them" society, in which women wearing a fullface veil, willingly or not, are sidelined by the state. Such extreme situations, in which veiled women become invisible to society must be avoided as much as situations in which women are considered a hazard to society and are prevented from wearing burkini on the beach as seen in France in the summer of 2016.

Empirical findings, such as those presented by Silvestri ${ }^{86}$ and Brems, ${ }^{87}$ are crucial for understanding the reason why the veil is perceived as emancipatory by some women. It is also necessary to develop a theoretical framework based on socio-legal studies to assess the importance of the actions of the Court with regard to veiling and unveiling. My focus of the ECtHR is explained by the fact that the Court plays a crucial role in changing the judicial landscape of Europe. The Court is in a position to influence the behaviour of its member states with regard to multiculturalism, interculturalism, and cultural diversity, often referring to a broad margin of appreciation in the matter. This is why the ECtHR needs to be encouraged to realize what the consequences of its decisions are for the European Muslim minority. Judges should be encouraged to examine

86 Silvestri, supra note 78.

87 Eva Brems, The Experiences of Face Veil Wearers in Europe and the Law (2014). 
the issue of religion and secular affairs differently, by analyzing the narratives of veiled European Muslim women, to reflect their needs and protect them better. The dynamics of rights vs societal change is thus at the core of the issue at hand. The ECtHR is expected not only to voice an opinion on the limits of freedom of religion under Article 9; it is also expected to weigh in on the role of religion in society and to understand that part of its mission is to mediate between law and social practices to reinforce social cohesion. The Court, therefore, plays an important role in bringing all identities and legal subjectivities together under the umbrella of the law. This is why I call for the Court to develop an all-inclusive framework and instruments to deal with religion and symbols of religion in public life, beyond the margin of appreciation.

The question of bias and of preferential treatment may be raised if the Court were to consider subjective narratives of a minority. Such an argument, however, would not take into consideration the stakes of the passport veil that exist for the Muslim minority, such as women's empowerment. Indeed, the issue goes beyond the passport veil; it is also about how the ECtHR approaches the role of religion, pluralism, multiculturalism, and interculturalism in Europe. The ECtHR should endeavour to examine the issues that are deeply embedded in society, such as social characteristics, by listening to those who struggle to contribute to living together, so that their inclusion may be improved. The German Constitutional Court has followed this path in a decision ${ }^{88}$ in which it took into account the discrimination that women encountered when veiled. Judges considered the fact that women were forced to deny their religion to obtain employment and good living conditions. Such inclusion of alternative views about women did not constitute a preferential treatment but a way of accommodating the other to reinforce social cohesion. Consequently, my experiment raises the question of the role of courts when it comes to addressing multiculturalism and to "re-orient legal thinking to allow adequate recognition of (these) conditions." ${ }^{89}$

\subsection{Social Cohesion and Living Together}

The $S A S$ case, followed by the 2017 cases, curbed freedom of religion on the basis of protection of living together. The rationale for these decisions was that the full and partial face veil undermined the social cohesion of France, and the country could rely on its wide margin of appreciation to interfere with freedom of religion:

\footnotetext{
88 Ludin v. Land Baden-Wurttemberg ("Lehrerin mit Kopftuch"), 2 BvR 1436/o2, 24 September 2003 .

89 Roger Cotterrell, "Culture, Power and the Human Animal: A Reply", 4 Int J. L. C. (2008), 407.
} 
The Court takes into account the respondent State's point that the face plays an important role in social interaction. It can understand the view that individuals who are present in places open to all may not wish to see practices or attitudes developing there which would fundamentally call into question the possibility of open interpersonal relationships, which, by virtue of an established consensus, forms an indispensable element of community life within the society in question. The Court is therefore able to accept that the barrier raised against others by a veil concealing the face is perceived by the respondent State as breaching the right of others to live in a space of socialisation which makes living together easier. ${ }^{90}$

Although the concept of living together is a "very general concept," as well as "far-fetched and vague," 91 it still has a deep meaning and emphasizes the idea of "us versus them." In this rhetoric, the other, the veiled Muslim woman, is showing her inability or refusal to integrate in society and should therefore be side-lined for fear of affecting national cohesion. She is thus reduced to being a veiled woman rather than being a woman wearing the veil. In contrast, the argument of the passport veil rejects the idea that women refuse integration. It relies on research analyzing why women veil wear the veil to integrate society. ${ }^{92}$

Cotterrell's perspective that justice acts as a lubricant for the mechanisms of society to "ensure smooth, complex interplay of social and economic roles and functions ${ }^{93}$ " is challenged in these circumstances. According to Cotterrell, the role of the law is to remove barriers and actively motivate individuals to play their part into society. I believe this is also true of the courts. Courts play an important role through their contribution to democracy and human rights, both of which are elements framing the mission of the ECtHR. By citing the need to keep social cohesion intact, to ensure that all live together, the Court plays its role as a lubricant. This is accomplished, however, at the expense of social, cultural, or religious values, integrating or excluding these values according to the benchmark of the margin of appreciation.

The Court adopted the French idea that social cohesion is defined as our ability to rally around common values, rejecting the other as unfit. As summed

\footnotetext{
$90 \quad S A S$ v. France, $§ 122$.

91 Dissenting Opinion, sAS v. France, §5.

92 Open Society Foundation. 2011. "Unveiling the truth: why 32 Muslim women, wear the fullface veil in France". Open Society Foundation. Retrieved 17 February 2017, http://www .opensocietyfoundations.org/sites/default/files/a-unveiling-the-truth-20100510_o.pdf 
up by a French politician, "social cohesion presupposes acceptance that others can look at you." ${ }^{94}$ This acceptance seems to be denied to citizens when others are veiled, causing a sense of unease, as demonstrated by the facts of the Dahlab case and by the security argument put forward in the Belcacemi and Oussar case. It then becomes the mission of the Court to ensure that there is no social conflict in upholding social cohesion. Yet, that consideration of the principle of "living together" would lead to the marginalization of some citizens, denying them the opportunity for upward mobility. The current case law demands a reevaluation of the social contract to reflect on how we consider European veiled Muslim women and of the role they can play in society and the contribution they can make to it. None should be excluded, and the Court should be reminded that "the collective thrives by allowing individuals to thrive." 95 Furthermore, marginalization can have uncontrolled effects, such as driving religious, cultural, and traditional practices underground, threatening women's rights.

The Court is in a position to renegotiate the social contract and make it more inclusive. In this regard, Binmore's model, ${ }^{96}$ distinguishing between social norms and social preferences is relevant to the passport veil. In the current state of affairs, the ECtHR considers undefined social norms as paramount (for example, public safety) as the expense of social preferences. According to Binmore, however, social preferences should be respected to encourage social bonding and collective life. Rather than excluding and losing individual elements, everything must be done to include them to ensure social cohesion. The idea is to maximize the freedom of the individual to choose within a framework, knowing that preferences are limited by preferences of others. As explained by Gintis, however, "social norms are an emergent property of human sociality, and exist as macrosocial structures that are not reducible to the preferences of individuals." 97 Binmore noted that it is indeed difficult to "formulate a coherent theory of social preferences unless one has a systemic model of social norms existing outside of the system of individual preferences."98 The ECtHR is asked to mediate social preferences and social norms, without

94 Bill prohibiting concealment of the face - Speech by Michèle Alliot, Ministre d'Etat, Keeper of the Seals, Minister of Justice and Freedom, at the Senate (excerpts), Paris, September 14 , 2010, http://www.ambafrance-us.org/spip.php?article1853.

95 Ibid.

96 Ken Binmore, Natural Justice (2005).

97 Herbert Gintis, "Reply to Binmore: Social Norms or Social Preferences?" 2011. Retrived 17 February 2017, http://www.umass.edu/preferen/gintis/ReplyToBinmore.pdf.

98

Ibid. 
leaning toward an untenable individualism. ${ }^{99}$ In that regard, the rationale of the UN Committee when addressing the refusal by India to renew a residence permit without a bareheaded photograph is of interest. It questioned the arguments made by India that an ID photograph of a Sikh with a turban was a security issue. The committee proposed a shift of burden from the individual to the state, arguing that unless the state was able to determine the security threat, freedom of religion has to be respected. Social preferences are therefore tolerated as long as the state cannot prove that they are harmful to social cohesion. ${ }^{100,101}$

Social preferences should therefore not be a factor in the exclusion of European Muslim women wearing a veil from membership in society. This represents a challenge for the Court, which must ensure a strong attachment to society at the micro and macro levels. I believe the veil constitutes an excellent passport for this membership, if the veil is approached as an indicator or "membership attitude"102 rather than what severs or weakens the link to society. I believe that tolerance of social preferences such as the passport veil will empower women experiencing a cognitive dissonance to fully belong to the European public sphere; it is best than a model of social cohesion according to which individuals are expected to show loyalty by unveiling.

\subsection{The Approach of the Court to the Veil: A Theological Argument or a Subjective Narrative?}

Judges appear not to be engaging with religion outside Article 9. Religion remains largely unintelligible to the Court and the States, to the extent that "erasing its public evidence seems to have become the most unanimously adopted posture." 103 This is why having experts provide knowledge about the different views on the veil would be useful. For this experiment to take place, the following question of method must be answered: How is the Court expected to proceed when considering accommodating alternative religious perspectives? Should the Court focus on a theological argument, assessing the multiple understandings of the veil, as I suggested above? Or should it, instead, rethink the

\footnotetext{
99 Herbert Gintis, The Bounds of Reason: Game Theory and the Unification of the Behavioral Sciences (2009).

100 Ranjit Singh v. France, Communication No. 1876/2009, U.N. Doc. CCPR/C/102/D/1876/2009 (2011), § 8.4.

101 Peter M. Gerhart, Tort Law and Social Morality (2013), 16.

102 Noah E. Friedkin, "Social Cohesion", 30 Annu. Rev. Sociol (2004), 409.

103 Valerie Amiraux, “The 'illegal covering' saga: what's next? Sociological perspectives” 19(6) SI (2013), 794-806, 798.
} 
balance between state and society on one hand, and individuals on the other. This is an important question because it addresses the role of the judge: Should judges consider religious, cultural, or traditional matters, or should they look into personal motivations?

The Court has conducted theological assessments in the past. ${ }^{104}$ This is why I argue for such an assessment: it addressed the veil as a religious instrument for purposes of proselytizing and coercion. The Suku Phull case on the turban ${ }^{105}$ illustrates this tendency: in that case, the judges looked at the turban as a religious obligation. The ruling is mitigated by the Mann Singh case, in which the Court looked into individuals' beliefs rather than into theology, stating that:

[a]ccording to the applicant, the Sikh faith compels its members to wear a turban in all circumstances. It is not only considered at the heart of their religion, but also at the heart of their identity. Consequently, the Court notes that it consists of an act motivated or inspired by a religion or a conviction. ${ }^{106}$

Later, however, the Court returned to making theological assessment as to whether or not the turban was compulsory. ${ }^{107}$ Two options are available in my experiment: the ECtHR could either go back to the Mann Singh case, which focuses on a subjective individual narrative, or retain its theological approach and consider other readings of a religious instrument. I have proposed a theological argument in this article, based on the preferences of the Court, but an argument in favour of considering subjective narratives exists, and has has also appeared in this article, indirectly.. Subjectivity was considered in Raihon Hudoyberganova v. Uzbekistan, which involved coercion (a student was expulsed from university for refusing to remove her veil), ${ }^{108}$ as Ms. Hudoyberganova's status as a victim was acknowledged.

For the sake of our experiment, note that another forum, the UN Human Rights Committee, approached the issue of the turban differently, questioning

\footnotetext{
104 See the analysis by Saila Ouald Chaib, "Suku Phull v. France rewritten from a procedural justice perspective: Taking religious minorities seriously", in Eva Brems (ed.), Diversity and European human rights: Rewriting judgments of the ECHR (2013), 218-242, 229.

105 Suku Phull v. France, 35753/03 [2005] ECHR (11 January 2005).

106 Mann Singh v. France, 24479/07 [2008] ECHR (27 November 2008).

107 Jasvir Singh v. France, 25463/08 [2009] ECHR (30 June 2009) and Ranjit Singh v France 27561/08 [2009] ECHR (30 June 2009).

108 Raihon Hudoyberganova v. Uzbekistan, Communication No. 931/2000, Views of 5 November 2004 .
} 
whether the wearing of a turban would affect safety by preventing proper identification. In its reasoning, the Committee focused on the right of the individual, which it stated that needed to be protected. ${ }^{109}$ The Committee balanced the collective and individual rights differently from the ECtHR, to prevent unnecessary curbing of freedom of religion, and considered that the state rationale of public safety was not demonstrated in this case:

[E]ven if the obligation to remove the turban for the identity photograph might be described as a one-time requirement, it would potentially interfere with the author's freedom of religion on a continuing basis because he would always appear without his religious head covering in the identity photograph and could therefore be compelled to remove his turban during identity checks. ${ }^{110}$

Therefore, the Committee examined the indirect consequences of an ID photo without turban for an individual whose identity was associated with his religious beliefs. The position of the Committee demonstrates that it is possible to have a better understanding of the applicant's religious, cultural, and traditional views, than that demonstrated by the ECtHR as long as such elements do not undermine public safety and as long as the state if able to define, explain, and justify such a threat. The Committee did not seek to debate any religious, cultural, or traditional beliefs that would be problematic, but rather to find a better-suited yardstick. The yardstick remains the necessary limitation of individual freedom of religion to protect state interests, if the state is able to demonstrate a risk. The position of the Committee illustrates that it is possible and necessary to ask real questions rather than use broad concepts such as public safety and living together at face value. This approach of the Committee shows that the wide margin of appreciation of the ECtHR must be reconsidered and the balancing that leads to the "sacrifice"111 of individual rights questioned. In January 2015, the German Constitutional Court concluded that although it was possible to curb individual human rights to protect the interests of the state, such limitation would have to be based on concrete facts rather than prejudiced views. ${ }^{112}$ There should be sufficient concrete evidence that

\footnotetext{
109 Ranjit Singh v. France, supra note 159.

110 Ibid.

111 Bikramjit Singh v. France, Communication No. 1852/2008, U.N. Doc. CCPR/C/106/D/1852/ 2008 (2013), § 8.7.

112 Case unnamed, 1 B v R 471/10 and 1 B v R 1181/10, 27 January 2015.
} 
wearing the veil by a teacher would undermine the peaceful atmosphere in the school. Domestic courts have therefore taken the lead in this matter, using a contextualized approach to the veil, taking Islamophobia into consideration, and showing respect for women's religious identity. Nevertheless, the difficulty of practicing cultural diversity in the courts remains a reality, as stressed by Shachar. ${ }^{113}$ Yet, the ECtHR could practice cultural diversity by providing "an adequate balance between respecting cultural difference and protecting individual rights." 114

The reason for arguing in favor of the consideration of an "individual exogenous factor(s)"115 or for a theological argument is that it may help reinforce national cohesion. In the case of the passport veil, considered either as a subjective individual statement, or from a theological point of view, I argue that it is necessary for the Court to be aware of the existence of an alternative understanding of the role of the veil. Such understanding would give a whole new meaning to living together and to the content of social cohesion.

\section{5}

\section{Conclusion}

By integrating Islamic feminism in its considerations on veiling into a secular context, the Court could enrich its vision and provide better protection of freedom of religion. This demands a more coherent approach to the margin of appreciation, using such elements as the passport veil. This also means that the Court needs to start regarding Muslim women wearing a veil as empowered subjects, rather than seeing them as victims and objects. The Eremia case may contribute to this shift, as it focuses on the effect that law has on women, regarding them as subjects, ${ }^{116}$ as does the Hudoyberganova case, which considered the effect of being ousted for a student. ${ }^{117}$ In the Eremia case, the applicant was the victim of domestic violence, who argued that the state had failed to protect her, in breach of the law. The ECtHR supported that argument and investigated the effect that legislation and its breach have on vulnerable

\footnotetext{
113 Shachar, supra note 5 .

114 Shachar, supra note 71, 88.

115 Hector Fix-Fierro, Courts, Justice, and Efficiency: A Socio-legal Study of Economic Rationality in Adjudication (2004), 55.

116 Eremia and Others v. the Republic of Moldova (28 May 2013).

117 Raihon Hudoyberganova v. Uzbekistan, § 50.
} 
individuals. ${ }^{118}$ The argument followed by the Court was that domestic violence affects women disproportionately and differently, which should be considered in the decision. ${ }^{119}$ The ECtHR appears to have shifted its substantive approach to equality under Article 14 and its approach to formal equality to a focus on harm and indirect discrimination. The Eremia case investigated the way in which discrimination is experienced from the perspective of the victim, examining the effects of a law to evaluate whether it causes or perpetuates disadvantage, discrimination, exclusion, or oppression. The shift of focus is a crucial change of perception, which could affect Muslim women positively, possibly addressing their cognitive dissonance, now that the focus is on how discrimination is experienced. In Europe, Muslim women experience multiple identities, and at times struggle to reconcile their religious beliefs with societal beliefs. This can create a cognitive dissonance: veiled Muslim women struggle to reconcile their belief in wearing the veil with their contribution to society. ${ }^{120}$ This dissonance can be exacerbated by decisions such as the ones in domestic or regional courts that describe the veil as a threat to the secular order or an instrument of women's oppression. Thanks to the Eremia case, the Court can now change the focus on the veil from that of a tool of propagation of extremism and oppression to examining the disadvantage, discrimination, exclusion, and oppression experienced by veiled women. ${ }^{121}$

The integration of veiled Muslim women in society is of great importance for human rights as well as for the evaluation of the role of culture, religion, and traditions in Europe. I do not suggest that all beliefs and values should be accommodated, but that the ECtHR must refine its test to ensure at least proper consideration before discarding them, if necessary, in a clear and constructive manner. The way in which the Court addresses the issue of the veil can have a beneficial effect on multiculturalism, and perhaps on interculturalism. The hope is that the experiment suggested in this article provides an

118 Eremia case, supra note $170, \S 50$ and $\S 60$.

119 Ibid., §6o.

120 Yvonne Yazbeck-Haddad, Muslims in the West: from Sojourners to Citizens (2002), 115.

121 This shift is completed by another important change in the Court's reading of Article 14: in the B.S. v. Spain case (B.S. v. Spain 47159/08 [2012] ECHR (24 October 2012), the Court adopted an intersectional approach which is an important contribution to the consideration of feminist theories (Keina Yoshida, "Towards intersectionality in the European Court of Human Rights: the case of B.S. v Spain" 21(2) Fem. Legal Stud. (2013), 195). Integrating intersectionality completes the changes brought to perceptions of discrimination and its effect on the outcomes on Muslim women. 
illustration of both multiculturalism and interculturalism. I built on Cantle's view who wishes to see culture and religion in constant evolution, which led me to the idea of a passport that enables crossing borders. I also challenged the idea of tolerance of Islamic feminism, as "tolerance always presupposes a control over what is tolerated." ${ }^{22}$ My suggestion was rather for the ECtHR judges to embrace diversity by supporting the creation of European Muslim women's identities.

122 Ghassan Hage, White Nation: Fantasies of White Supremacy in a Multicultural Society (2000), 89 . 